\title{
REVISTA DE PESQUISA INTERDISCIPLINAR: UMA CONTRIBUIÇÃO PARA O DESENVOLVIMENTO TÉCNICO-CIENTÍFICO-ACADÊMICO DA ÁREA INTERDISCIPLINAR
}

Cristina Novikoff

A Revista de Pesquisa Interdisciplinar (RPI) nasce no Centro de Formação De Professores da Universidade Federal de Campina Grande CFP/UFCG, no campus de Cajazeiras, sertão da Paraíba onde concentram cursos das áreas das ciências exatas e da natureza, ciências sociais, ciências humanas e saúde.

A Revista de Pesquisa Interdisciplinar é um sonho em materialização do Laboratório do Grupo de Estudos e Pesquisas em Representações Sociais na/para Formação de Professores - LAGERES/CNPq (2010) que sempre acreditou na interdisciplinaridade e promove anualmente o Seminário Analítico Internacional de Temas Interdisciplinares - SIAT \& Seminário de Pesquisa Inovadora na/para Formação de Professores - SERPRO.

Com seu rico comitê editorial, a Revista de Pesquisa Interdisciplinar agrega novos territórios científicos para expandir sua força dialógica e se transformar em convite aberto aos interessados nesse movimento rizomático em sentido filosófico e político, para o exercício da leitura e escrita do pensamento interdisciplinar dentro das ciências multidisciplinar da CAPES, em especial, os relacionados às áreas de conhecimento de meio ambiente e agrárias, sociais e humanidades e saúde e biológicas.

Os textos, frutos de estudos tanto em grupo como individualmente serão bem vindos, uma vez que a RPI guarda coerência epistemológica com Jantsch e Bianchetti em relação à ideia de que é possível ser interdisciplinar a sós, além de sê-la em grupo. Acreditamos que um grupo pode ser mais homogêneo e superficial que o indivíduo que busca recursos de várias ciências para explicar determinado processos. São bons exemplos as obras de Marx, Piaget, Gramsci, Weber, Florestan Fernandes e outros.

Nesse sentido, pensar e compartilhar estudos na área interdisciplinar em grupo ou individualmente como forma de enfrentamento da cultura científica disciplinar hegemônica é o caminho eleito da RPI. Portanto, privilegiamos a imaginação criadora para dialogar com os leitores e seus inúmeros objetos de conhecimento de modo a 
instigá-lo a superar o medo do encontro com o outro desconhecido e navegar em espaços científicos e acadêmicos que se reinventam no processo de autoformação, da poiésis.

Se em amiúde, a palavra revista expressa ato ou efeito no sentido dicionarizado "de revistar, de examinar detidamente, de rever; inspeção, exame detalhado, enumeração, segunda vista ou verificação", esperamos dos leitores tal ato associado ao de curiosidade, criticidade e participativamente.

Finalmente, importa para a RPI apresentar ao público de leitores interessados em estudar e/ou difundir as possíveis estratégias das rupturas epistemológicas e seus métodos como apresentação ou provocação do pensar e fazer pesquisa de natureza interdisciplinar. 